http://dx.doi.org/10.11646/phytotaxa.127.1.10

\title{
Stephanodiscus Ehr. species from Holocene sediments in the Faiyum Depression (Middle Egypt)
}

\author{
R.J. FLOWER ${ }^{1}$, K. KEATINGS ${ }^{1}$, M.A. HAMDAN ${ }^{2} \&$ F.A. HASSAN ${ }^{3}$ \\ Department of Geography, University College London, Gower Street, London, UK \\ E-mail: rflower@geog.ucl.ac.uk (corresponding author) \\ ${ }^{2}$ Department of Geology, University of Cairo, Cairo, Egypt \\ ${ }^{3}$ Institute of Archaeology, University College London, Gordon Square, London, UK
}

\begin{abstract}
Lake Qarun in the Egyptian Faiyum Depression is the shrunken remnant of a much larger lake. To investigate the sedimentary history of the former lake, several continuous lacustrine sediment cores were collected from now terrestrial locations within the basin. The suitability of these sediments for reconstructing past environmental changes was first assessed by describing the gross stratigraphies of three core sequences and secondly by evaluating taxonomic issues concerning sedimentary diatom species within the genus, Stephanodiscus Ehr. The stratigraphic descriptions show basal sections comprised of either coarse sand or weathered Ecocene limestone overlain by lacustrine sediments. Lower sections of the lacustrine sediments are diatom marls, and, in the two lakeside cores, these are laminated. These sections indicate that the lake initially formed by rapid in filling to a considerable depth with freshwater and the diatom-rich marls containing abundant Stephanodiscus and Aulacoseira Thwaites species. A new species and variety of Stephanodiscus, $S$. neoaegypticus and $S$. neoaegypticus var. fekrii, are described from the marl section in one core. Another species, $S$. galileenis Håkansson \& Erhlich, was also present and is re-evaluated with reference to the published description. The importance of establishing a sound taxonomic foundation for palaeolimnological studies of Lake Qarun is stressed.
\end{abstract}

\section{Introduction}

Egypt possesses few natural inland lakes but modern day Lake Qarun in the Faiyum Depression is the remnant of a much larger early Holocene lake (Caton-Thompson \& Gardner 1934, Hassan 1986). Consequently, exploring sedimentary diatom records in Lake Qarun sediments can potentially help understand the environmental history of the lake. However, issues of sediment formation and dating, diatom preservation and diatom taxonomy all require careful evaluation before palaeolimnological information can be fully exploited (e.g. Flower et al. 2006). Previous work has decribed terrestrial diatomite exposures northeast of modern Lake Qarun (Aleem 1958) and later Przbylowska-Lang (1976) showed benthic diatom species of Synedra Ehrenberg (1830: 60) and Epithemia Kutzing (1844:33) to be more abundant in upper diatomites from the region. Furthermore, Mueller-Wilmes (1988) found several unknown Stephanodiscus Ehrenberg (1845: 72) species in Lake Qarun sediment as well as Stephanodiscus aegyptiacus Ehrenberg (1854: pl. 33/1, fig. 16). Stephanodiscus species are of particular interest because they no longer grow in the lake today (Fathi \& Flower 2003, Mansour 2008) and, being planktonic, are indicative of open lake conditions.

As part of a larger project to investigate the environment history of Lake Qarun (e.g. Keatings et al. 2010), several sediment augur cores where collected from the Lake Qarun basin. This paper firstly summarizes the gross stratigraphy of these cores and, secondly, evaluates some Stephanodiscus species present with in these cores. 


\section{Site Description and Field Methods}

Modern Lake Qarun $\left(29.487^{\circ} \mathrm{N}, 30.298^{\circ} \mathrm{E}\right)$ lies within the Faiyum Depression and the current surface lake water fluctuates around $-43 \mathrm{~m}$ below sea level. It is sustained by drainage of Nile water delivered into the Depression through the Bahr Yusef (Fig.1)

Field sampling: In April-May 2008 augur coring (see Flower et al. 2012) was undertaken at six locations and three of these yielded lacustrine sediment sequences. The three cores containing diatom remains were QARU9 and QARU10, collected at the southern margin of Lake Qarun, and GARK1, collected from within the Gharak region in the south-western part of the Faiyum (Fig. 1).

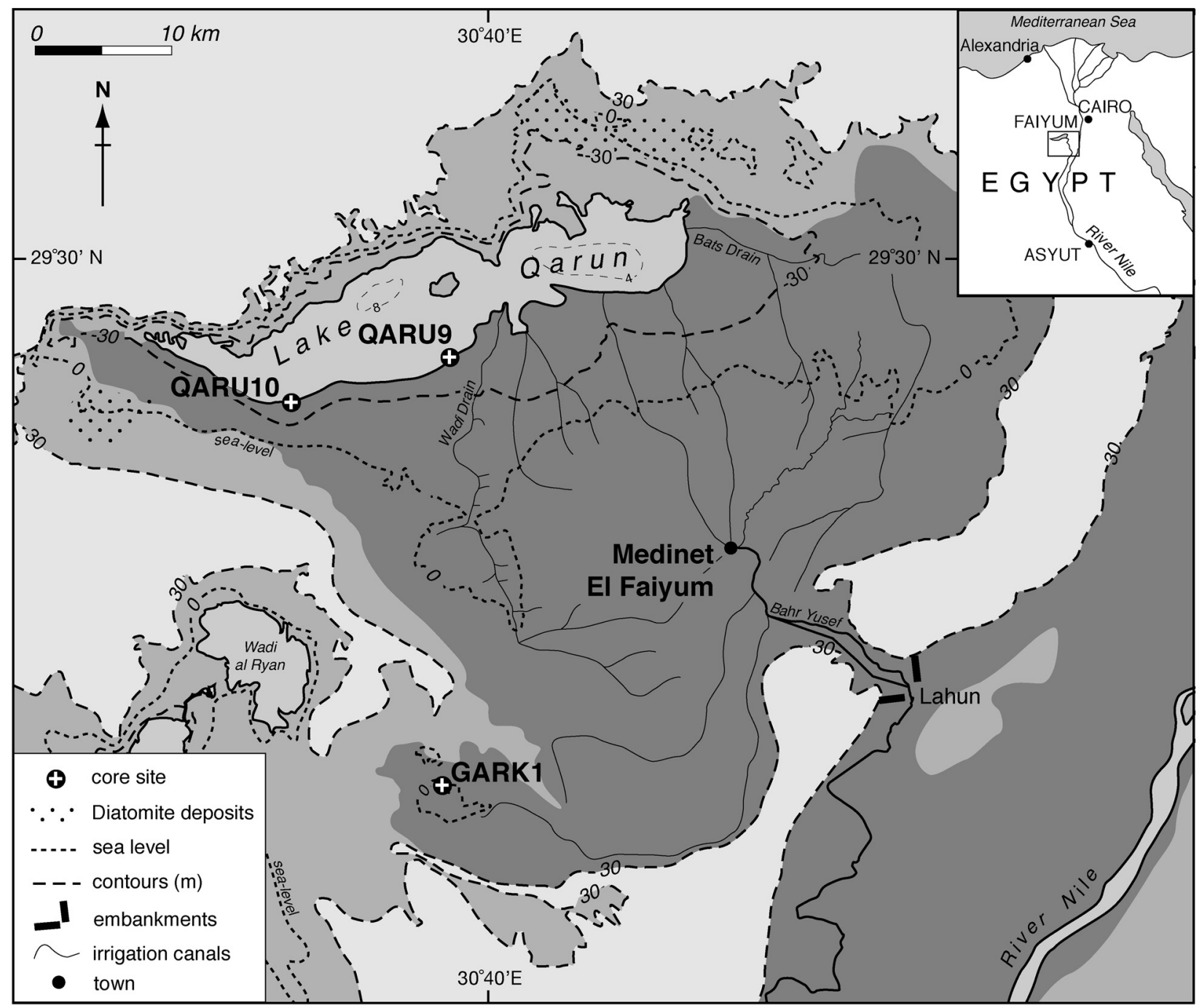

FIGURE 1. Lake Qarun situated in northern part of the Faiyum Depression, Egypt. Three terrestrial sediment core locations are shown with QARU9 and 10 on the southern shore of the lake and GARK1 in the Gharak region of south west Faiyum. Note diatomite exposures are indicated to the west and northeast of the modern lake.

Summary descriptions: QARU9 $\left(29.43447^{\circ} \mathrm{N}, 30.64213^{\circ} \mathrm{E}\right)$ was the longest core at $21.4 \mathrm{~m}$ and the upper sections consisted of a sandy layer and silty clays coloured dark brown to grey depending on depth (Fig. 2, left). Only below $1085 \mathrm{~cm}$ depth did the bulk sediment become coarsely laminated and below $1730 \mathrm{~cm}$ the white laminations became much thinner (at c. $1 \mathrm{~mm}$ thick) as the matrix changed to soft olive grey sediment. Below $2030 \mathrm{~cm}$ the sediment became silty and at c. $2080 \mathrm{~cm}$ coarse grey sand with small pebbles was present. QARU10 $\left(29.40309^{\circ} \mathrm{N}, 30.50830^{\circ} \mathrm{E}\right)$ was $10.4 \mathrm{~m}$ long (Fig. 2, middle) had a lithology similar to QARU9 but 


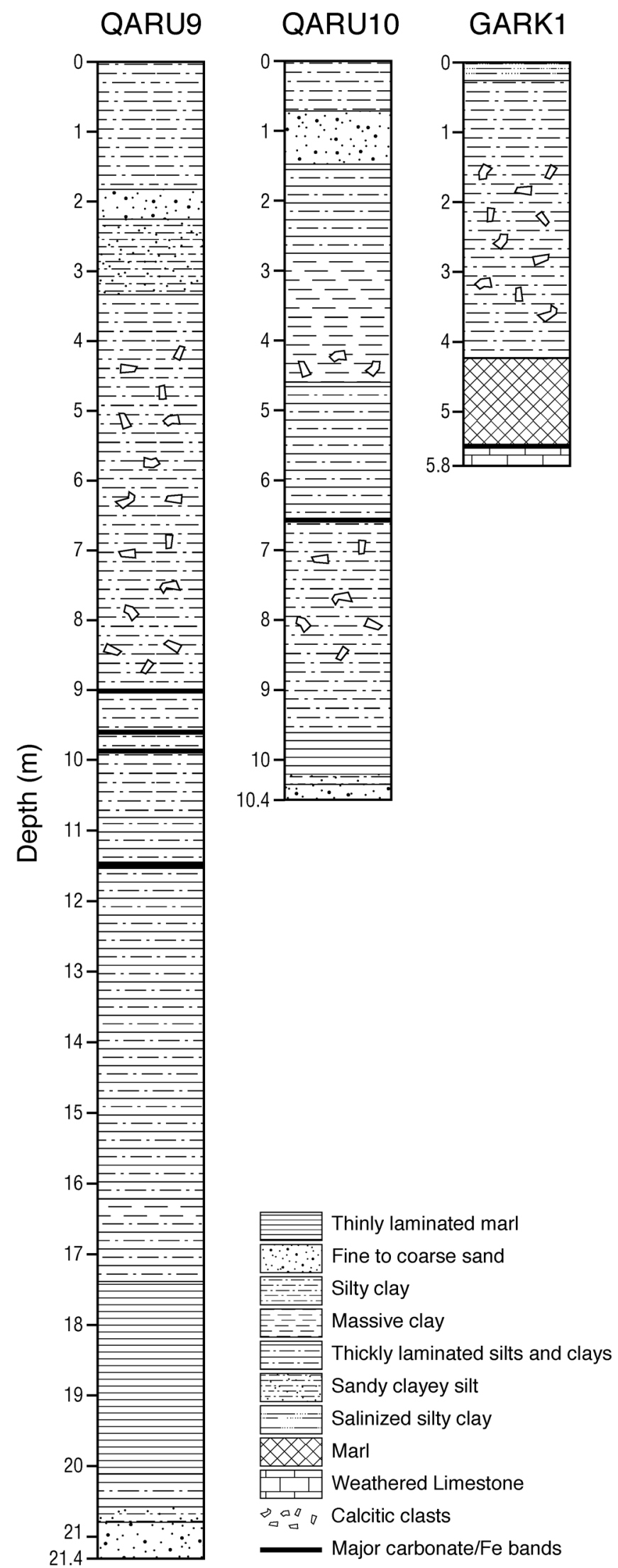

FIGURE 2. Gross sediment stratigraphies of the three cores, QARU9, QARU10 and GARK1 (see text for sediment descriptions). Note the basal sands below finely laminated diatom marl sediment in QARU9 \& 10 . 
with shorter sections. At around $960 \mathrm{~cm}$ fine laminations appeared but this section was shorter than in QARU9 being only about $60 \mathrm{~cm}$ in depth and by $1030 \mathrm{~cm}$ brown coarse sands and gravel occurred. GARK1 $\left(29.14840^{\circ} \mathrm{N}, 30.60976^{\circ} \mathrm{E}\right)$ was $5.80 \mathrm{~m}$ long (Fig. 2, right) and the upper sections comprised mainly silty clay but at $420 \mathrm{~cm}$ the sediment changed to a silty clayey grey marl which persisted to $570 \mathrm{~cm}$ with some feint irregular laminations. The sequence ended in light grey weathered limestone at $580 \mathrm{~cm}$.

Sample preparations: Sub-samples for preliminary diatom analysis were taken at approximately $40 \mathrm{~cm}$ intervals in each core with sampling frequency varying according to changes in stratigraphy. Most samples were placed into Whirl Pac bags for transportation from the sites. The bulk cores were all archived in Egypt for further lithostratigraphic study while the sedimentary diatom sub-samples were transported to the UK for diatom analysis.

\section{Material and Methods}

Initial low power microscopical examination of the down core diatom strews indicated that species of Cyclostephanos Round ex Theriot, Håkansson, Kociolek, Round \& Stoermer (1987: 346), Stephanodiscus and Aulacoseira Thwaites (1848: 167) and were common in many samples. In QARU9 at least some whole diatom valves were present in all samples between $160 \mathrm{~cm}$ and $2030 \mathrm{~cm}$ depth, in QARU10 between 260 and $1005 \mathrm{~cm}$ depth and in GARK1 between $60 \mathrm{~cm}$ and $580 \mathrm{~cm}$. Consequently, all samples were prepared for diatom analysis. After initial freeze drying, diatom analysis was undertaken after sample treatment with hydrogen peroxide (organic matter was $<10 \%$ of the dry sediment weight in all samples and little oxidation was needed). Hot $50 \% \mathrm{HCl}$, was used to remove carbonate minerals. After washing with distilled water, the resulting diatom suspensions were dried on to glass cover slips and mounted in Naphrax. Slide strews were examined at x1000 magnification in a Leitz Labrolux light microscope (LM) with a 1.3 N.A. objective so that diatom species could be assessed and taxonomic issues confronted. Because of the high degree of valve silicification, diatoms were usually viewed without phase contrast optics. Identification difficulties were soon encountered for species within the Stephanodiscus genus and appropriate treated samples from all three cores were used for taxonomic evaluation and photomicrography. LM microphotography used a Leica DM6000 LM with a 100 objective with a Zeiss AxioCam digital camera. Scanning electron microphotography was undertaken in a Jeol JSM-6480LV scanning electron microscope (SEM).

\section{Results}

Sediment core GARK1: Although not thinly laminated, the deeper $(4.2-5.6 \mathrm{~m})$ sediment in this core contained abundant planktonic diatoms which, in addition to Cyclostephanos dubius (Fricke) Round in Theriot et al. (1987: 346), included a Stephanodiscus species with similarities to S. aegyptiacus. This latter species was reviewed by Håkansson \& Locker (1981) and it is noteworthy that the type locality for S. aegyptiacus is the 'See Garag, Fajum, Aegypten'. The unrecognized Stephanodiscus species in GARK1 marl sediment was initially thought to be co-specific with $S$. aegyptiacus but closer examination in both LM and SEM revealed significance differences.

In the LM valves were large (up to $70 \mu \mathrm{m}$ in diameter) and weakly concentrically undulate so that frustules possessed only slightly differentiated convex and concave valves. No distinct sub-marginal hyaline silica ring was discernible at the valve face mantle junction (cf. S. aegyptiacus) although an indistinct ring (Fig. 3) is present in larger specimens (> c. $40 \mu \mathrm{m}$ diameter). Interfascicle ribs (3-4 in $10 \mu \mathrm{m}$ ) were relatively broad and tended to narrow both distally and proximally giving a fine lanceolate appearance (Figs 3, 4). Spines were absent although valves showing marginal dissolution can appear to have spines (Fig. 6). The fascicles are composed of areolae which in LM often appear large and blocky (Fig. 4), especially in well 
silicified specimens (Fig. 5). At the valve face-mantle junction (VFMJ), the interfascicles occasionally bifurcate (Figs $4 \& 5$ ). The fascicles are uniseriate for half to two thirds the length of the fascicle (dependant on valve size) and broaden at the VFMJ to include 3-4 areolae (Figs 4, 6-7). In smaller (<c. $40 \mu \mathrm{m}$ diameter) valves (Figs 7-8) the interfascicles appear relatively more lanceolate, depending on the plane of focus (Figs 7-8 ) and, compared to larger valves, they more frequently bifurcate at the VFMJ (Fig. 8).
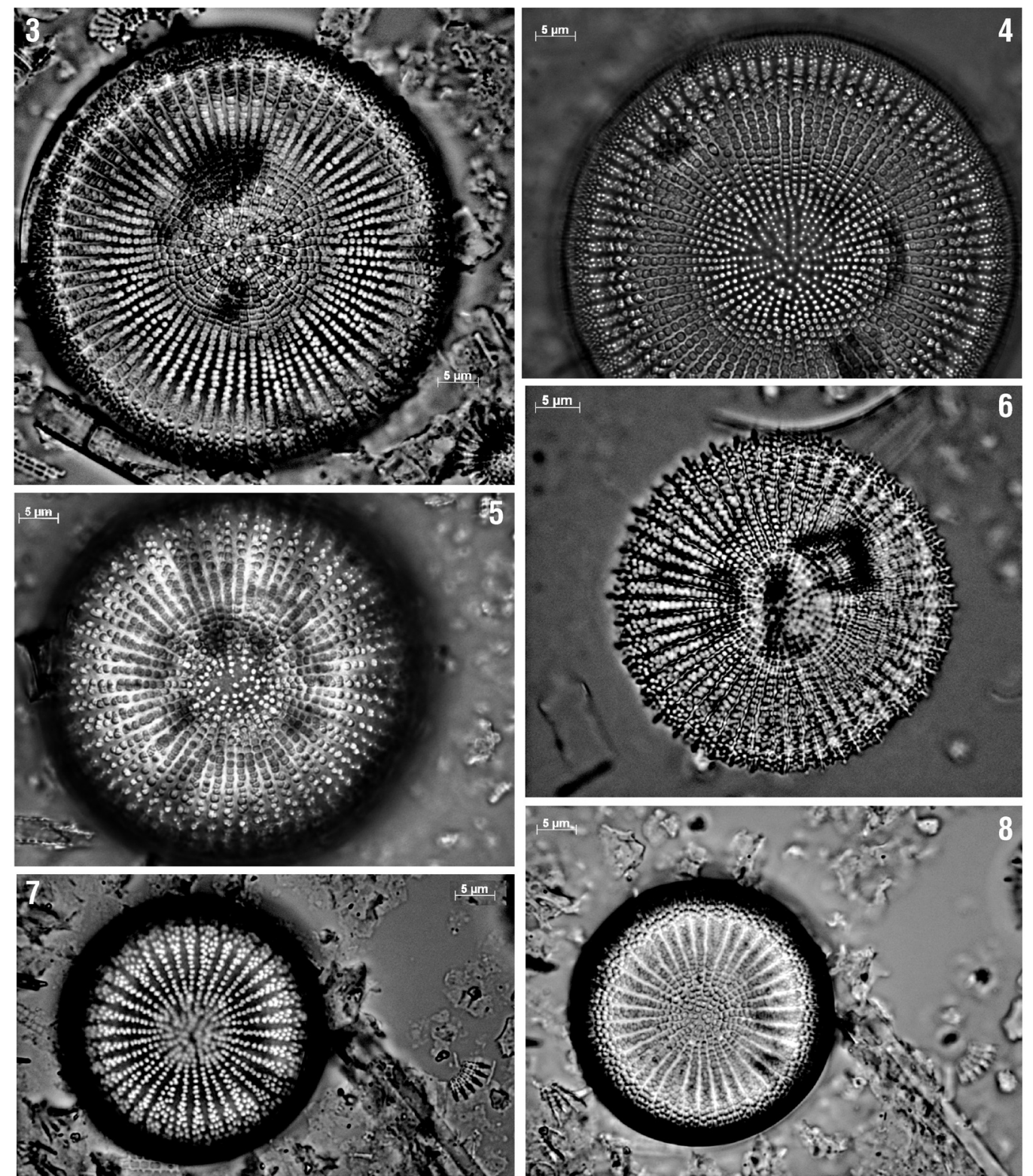

FIGURES 3-8. Stephanodiscus neoaegypticus, LM. Fig. 3. Valve showing an indistinct sub-marginal hyaline ring and broad interfascicular ribs. Fig. 4. Valve focused to show the valve face-mantle zone with occasional bifurcating interfascicular ribs (arrowed). Fig. 5. A strongly silicified valve. Fig. 6. A part dissolved valve with eroded margin and diminished interfascicular ribs. Figs 7-8. S. neoaegypticus v. fekrii LM. Fig. 7. Whole valve focused to show the broad interfascicular ribs and marginal bifurcations (arrowed). Fig. 8. The same whole valve (Fig. 7) focused to show the central area. Scale bars $=5 \mu \mathrm{m}$ (Figs 3-8)

In SEM the external valve view confirms only a small degree of concentric undulation with valves being slightly convex (Fig. 9) or concave (Fig. 10). The latter clearly shows the fine lanceolate nature of the flat interfascicles which narrow distally to accommodate broadening of the fascicles as they become multiseriate. External openings of the valve face areolae (c. 14 in $10 \mu \mathrm{m})$ are small $(<1 \mu \mathrm{m}$ in diameter, unless expanded by dissolution) and most interfascicles have external fultoportulae openings at the VFMJ (Fig. 10). External apertures of rimoportulae (Fig. 10, arrowed) are sub-marginal on interfascicles. Spines are absent. Internally, 
rimoportulae (3-6) occur irregularly spaced in the sub-marginal zone (Fig. 11, arrowed), are almost sessile and oriented sub-obliquely (Fig. 12). The areolae become markedly smaller beyond the VFMJ (Fig. 12) and more closely spaced ( $>30$ in $10 \mu \mathrm{m}$ ) compared to valve face areolae (c. 14 in $10 \mu \mathrm{m}$ ). Marginal fultoportulae have three satellite pores and are subtended by short tubes (Fig. 12). The central area fultoportulae form a ring and each possesses two satellite pores (Fig. 13, arrowed). Smaller valves ( $<$ c. $20-40 \mu \mathrm{m}$ in diameter) are also either concave (Fig. 14) or convex (Fig. 15) and valve face areolae appear more coarsely spaced with very small apertures (but metrics are not significantly different from those of larger forms). At least one raised rimoportula aperture occurs submarginally (Fig 14, arrowed). Internally, each valve has one, two or three marginal rimoportulae and a valve with two is indicated in Fig. 16. Marginal fultoportulae have three (sometimes four) satellite pores (Fig. 17). Central area fultoportulae are recessed with two satellite pores (Fig. 18, where well preserved domed cribra are also shown).
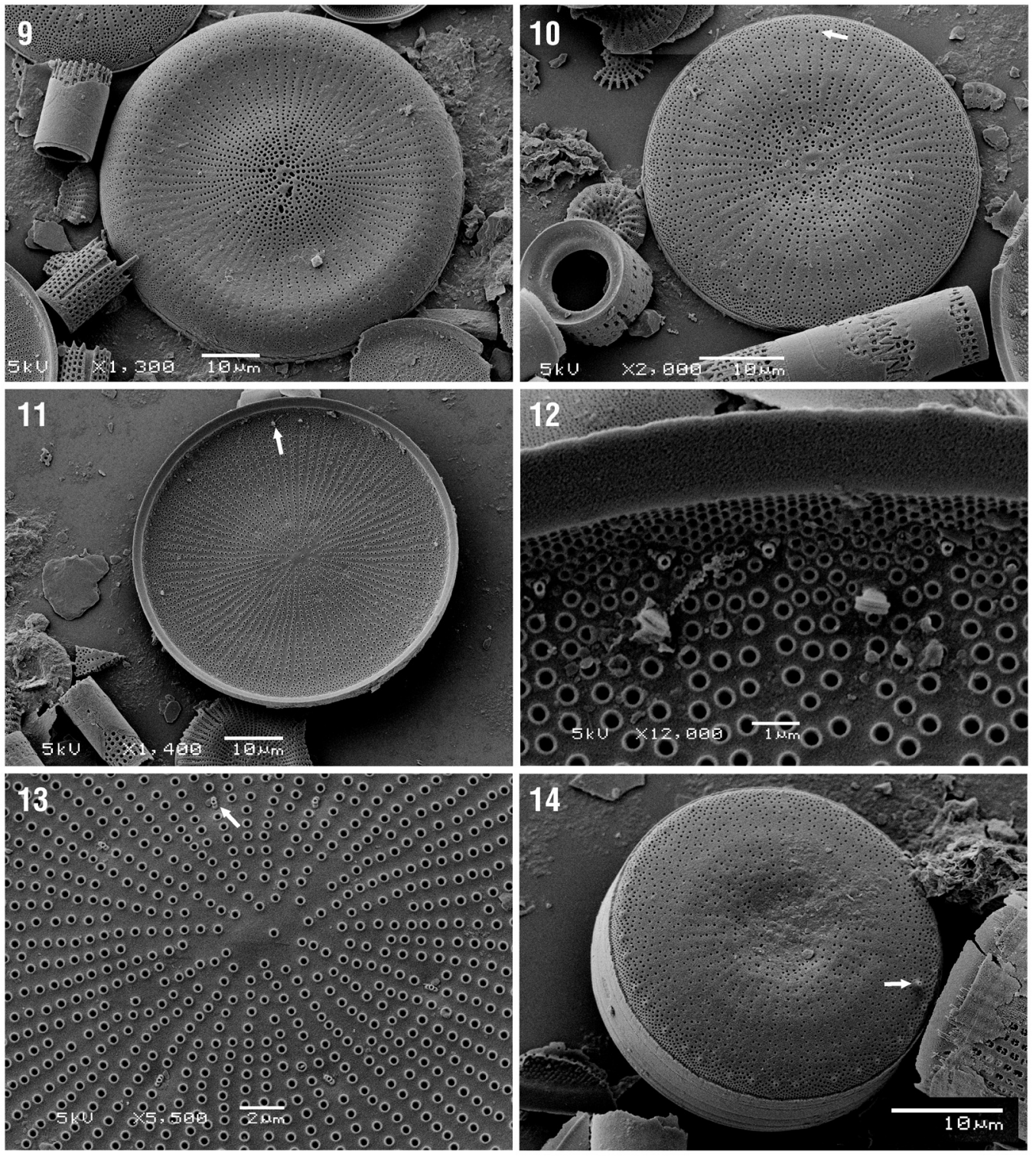

FIGURES 9-14. Stephanodiscus neoaegypticus, SEM. Fig. 9. Iconotype, external valve showing small concentric convex undulation with out spines. Fig. 10. External valve showing small concentric concave undulation and external rimoportula opening (arrowed). Fig. 11. Internal valve showing sub-marginal rimoportulae (arrowed). Fig. 12. Detail of the same valve showing two sub-marginal rimoportulae and marginal ring fultoportulae. Fig. 13. Detail of the central ring of fultoportulae (each with two satellite pores). Stephanodiscus neoaegypticus v. fekrii SEM. Fig. 14. Iconotype, external valve with a concave central area, marginal ring of fultoportula apertures and external opening of a rimoportula (arrowed). Scale bars $=10 \mu \mathrm{m}$ (Figs 9-11, 14), $1 \mu \mathrm{m}$ (Fig. 12), and $2 \mu \mathrm{m}$ (Fig. 13). 

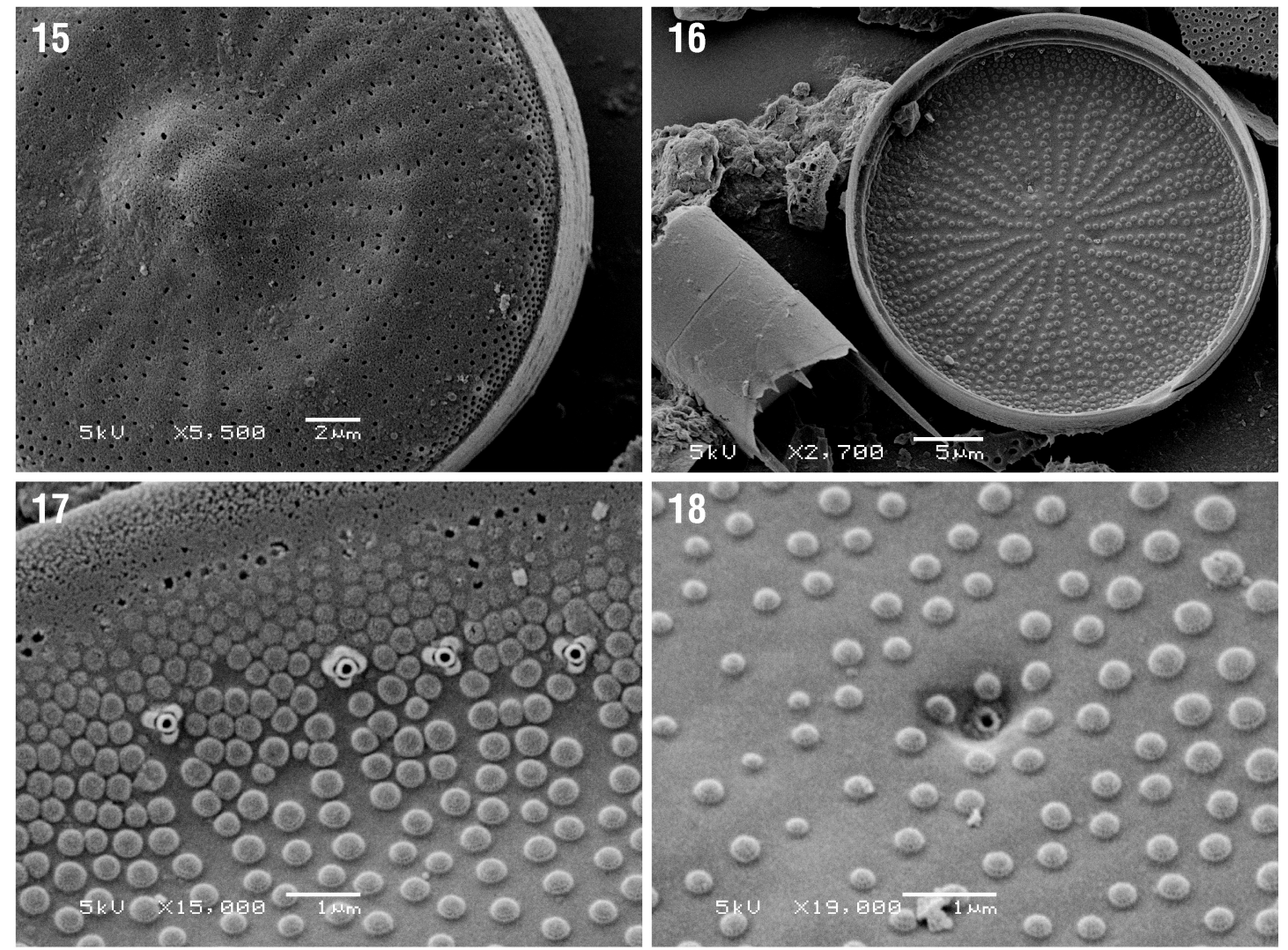

FIGURES 15-18. Stephanodiscus neoaegypticus v. fekrii, SEM. Fig. 15. External valve with a convex central area. Fig. 16. Internal valve showing two rimoportulae (arrowed). Fig. 17. Detail of internal marginal zone showing fultoportulae with either three or four satellite pores. Fig. 18. Internal central area fultoportula with two satellite pores. Scale bars $=2 \mu \mathrm{m}$ (Fig. 15), $5 \mu \mathrm{m}$ (Fig. 16), and $1 \mu \mathrm{m}$ (Figs 17, 18).

\section{New species descriptions}

\section{Division Bacillariophyta}

Class Coscinodiscophyceae F.E. Round \& R.M. Crawford in Round et al. 1990 emend. Medlin \& Kaczmarska 2004

Order Thalassiosirales Glezer \& Makarova 1986

Family Thalassiosiraceae Lebour 1930

Genus Stephanodiscus Ehrenberg

\section{Stephanodiscus neoaegypticus Flower sp. nov.}

Cells circular, undulate, central areas weakly concave or convex, spines absent. Cell diameters c. 30-70 $\mu \mathrm{m}$. Fascicles radial, uniseriate striae occupy about $2 / 3$ of the valve radius with 3-4 rows of areolae at valve face-mantle junction. Interfascicles distinct, not raised (compared to fascicles), circa $1.5 \mu \mathrm{m}$ wide around the mid radius, $4-5$ areolae in 10 $\mu \mathrm{m}$ at valve margin. External areolar openings small ( $1 \mu \mathrm{m}$ or less). Central area fultoportulae up to 6 , near valve centre, with two satellite pores. Marginal fultoportulae with three satellite pores at termini of interfascicles. External openings of marginal fultoportulae slightly raised. Rimoportulae sub-marginal, 3-6, oblique, irregularly spaced.

Type:-EGYPT. Gharak: Faiyum Depression, $29.43447^{\circ} \mathrm{N}, 30.64213^{\circ} \mathrm{E}$, Holocene lake sediment core (GARK1) material, sediment depth $450 \mathrm{~cm}$, collected April-May 2008, (Circled specimen (Fig. 3) on slide BM101659 (BM!), holotype, designated here). 
Stephanodiscus neoaegypticus var. fekrii Flower var. nov.

Cell diameters ca. $20-40 \mu \mathrm{m}$. Fascicles radial, uniseriate striae occupy ca. $50 \%$ of the valve radius. Interfascicles often divide beyond the valve face-mantle junction and slightly widen in the mid-valve region. Central area fultoportulae 2-3. Rimoportulae sub-marginal, 2-3.

Type:-EGYPT. Gharak: Faiyum Depression, $29.14840^{\circ} \mathrm{N}, 30.60976^{\circ}$ E, Holocene lake sediment core (GARK1) material, sediment depth $450 \mathrm{~cm}$, collected April-May 2008, (circled specimen (Figs 8, 9) on slide BM101660, holotype, designated here).

Sediment cores QARU9 and QARU10: In the thinly laminated sections of both QARU9 \& 10 (see Fig. 2), a third common Stephanodiscus species was present that was not $S$. neoeagyptiacus but much more similar to $S$. galileensis Håkansson \& Ehrlich (1987: 20). The type locality for this species is sub-surface (fossil) sediment in Lake Kinneret (Israel). They reported a heterovalvic condition where the concave and convex valves differed with regard to fascicle arrangement and to location of fultoportulae. Since some of their material was evidently rather poorly preserved (see their Figs 3, 14 and 16), the species is re-examined here.

In LM, Stephanodiscus galileensis valves show strong concentric undulations according to the plane of focus either on the marginal or central areas (Figs $19 \& 20$ ). Valves range from $20-48 \mu \mathrm{m}$ in diameter. The marginal area (Fig. 19) also displays a characteristic sub-marginal hyaline silica ring and broad interfascicles. Fascicles are c. 5 in $10 \mu \mathrm{m}$, proximally uniseriate with large blocky areolae becoming finer and bi- or triseriate in the distal third portion of the valve. Interfascicles are distinct and about $1.5 \mu \mathrm{m}$ broad in the midradius area. Concave valves show a similarly strong undulation (Figs 21 \& 22) with 5-6 hyaline areas (marking fultoportulae, see below) in the mid-radius position on the valve face (Fig 21, arrowed) and these are particularly obvious in well silicified specimens (Fig. 23). Fascicles on these valves (morphotype 'B' of Håkansson \& Ehrlich 1987) appear to contain finer areolae and are biseriate for about half the valve distal radius. In this region, interfascicles are often about $1 \mu \mathrm{m}$ broad but in strongly silicified specimens the width is similar to those in valves with hyaline sub-marginal rings.
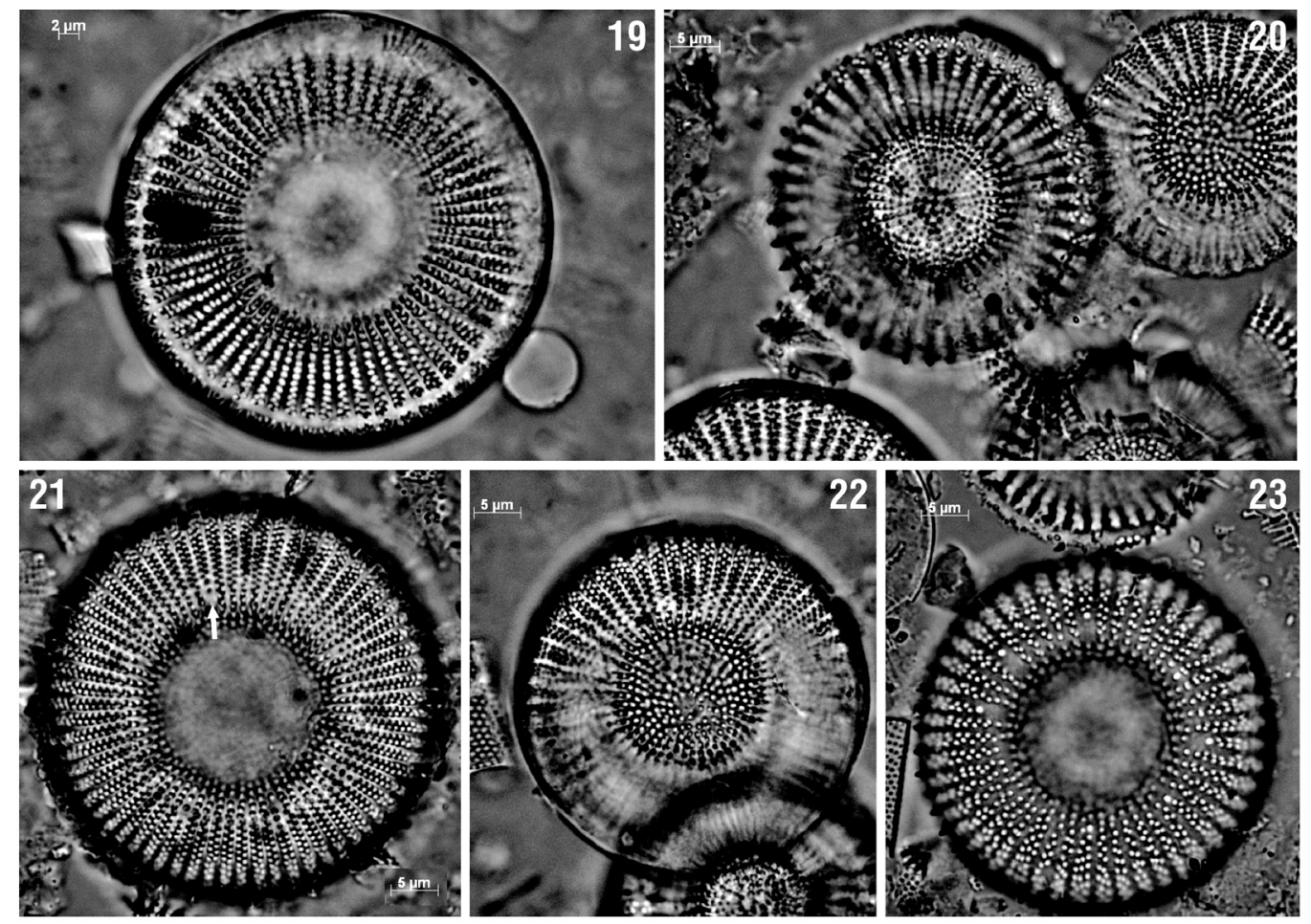

FIGURES 19-23. Stephanodiscus galileensis, LM. Fig. 19. Convex valve showing a distinct sub-marginal hyaline ring in focus. Fig. 20. Similar showing marginal ring of spines and valve central area in focus. Fig. 21. Concave valve showing finer fascicle structure (see S. galileensis morphotype B, Hakansson \& Locker 1987) and valve face fultoportulae (arrowed). Fig. 22. Similar showing valve central area in focus. Fig. 23. Similar, but valve is more strongly silicified. Scale bars $=5 \mu \mathrm{m}$ (Figs 19-23). 


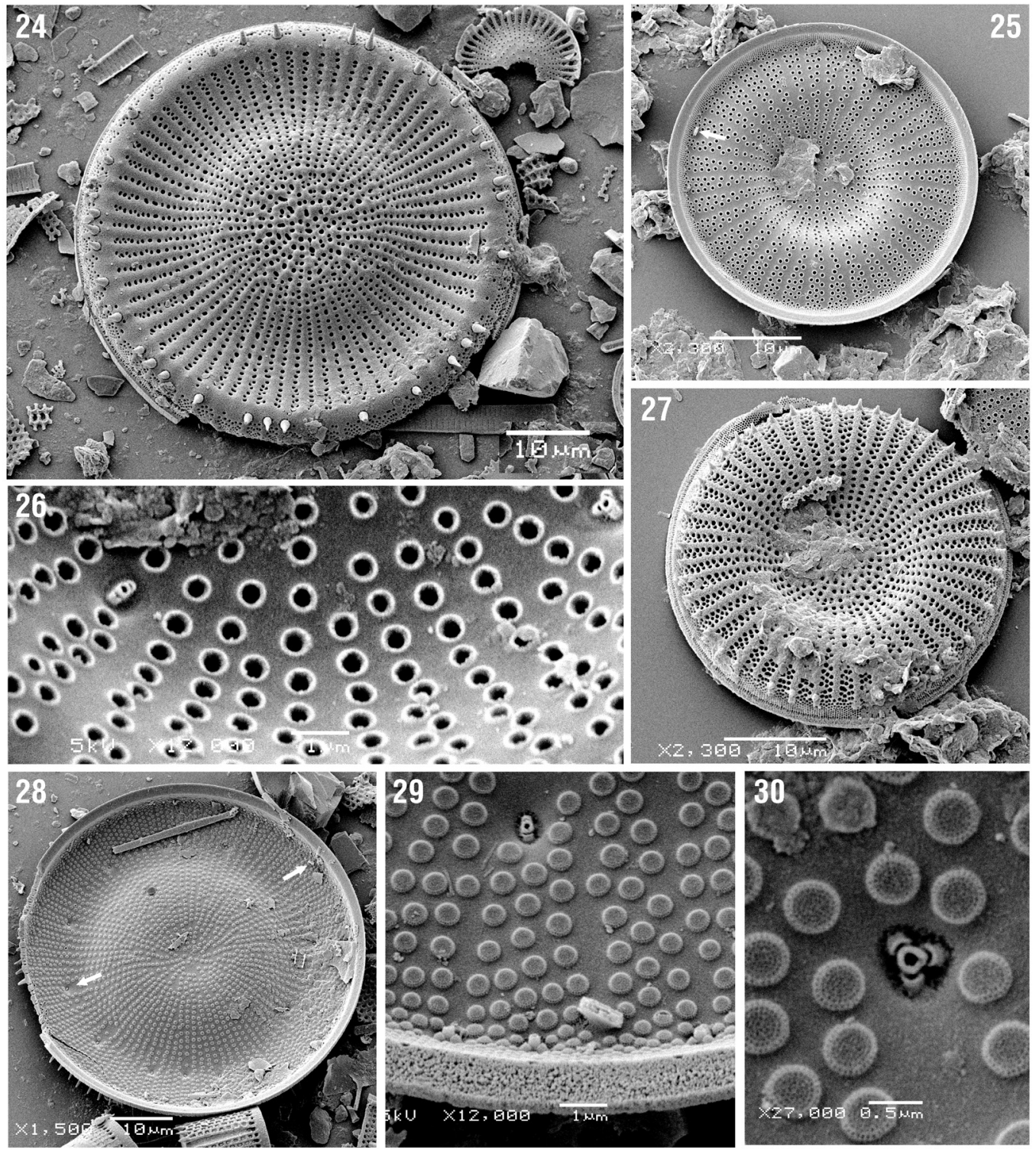

FIGURES 24-30. Stephanodiscus galileensis, LM. Fig. 25. External convex valve note irregular spines and sub-marginal silica ring. Fig. 25. Internal convex valve with rimoportula arrowed. Fig. 26. Detail of same valve showing central area ring of fultoportulae with two or three satellite pores. Fig. 27. External concave valve with ring of spines and raised interfascicular ribs. Fig. 28. Internal concave valve showing ring of sub-marginal fultoportulae and rimoportulae (arrowed). Fig. 29. Similar showing detail of a rimoportula, a submarginal fultoportula with two satellite pores and marginal fultoportulae. Fig. 30. Detail of a sub-marginal fultoportula with three satellite pores and surrounding domed cribra. Scale bars $=10 \mu \mathrm{m}$ (Figs 24, 25, 27, 28), $1 \mu \mathrm{m}$ (Figs 26, 29), and 0.5 $\mu \mathrm{m}$ (Fig. 30).

In SEM, the external view of convex valves of $S$. galileensis clearly shows the marked central undulation with irregularly spaced spines subtended from the sub-marginal silica ring (Fig. 24, note the similarity of this specimen with $S$. aegyptiacus as depicted in Fig. 63, Håkansson \& Locker 1981). The fascicles are uniseriate becoming biseriate or triseriate near the valve face-mantle junction (VFMJ) with small areolae (12-13 in 10 $\mu \mathrm{m})$. External areolar openings are generally $<1 \mu \mathrm{m}$ in the mid valve face area and, consequently, the fascicles are narrower than the interfascicles. Internally, these convex valves (Fig. 25) show marginal fultoportulae on each interfascicle at the VFMJ, one or two sub-marginal rimoportulae (arrowed) and a ring of central area fultoportulae (Fig. 26) with either two or three satellite pores. The mantle areolae, cribra and fultoportulae are generally as in Håkansson \& Ehrlich (1987) except in this material the number of central area processes is lower. The concave valves confirm heterovalvy (Fig. 27) with raised interfascicles each subtended by a spine, distinct external openings of central area fultoportulae (arrowed) and a greater degree of areolation (with distally extended bi- and triseriate fascicles) compared to convex valves. Internally, the 
concave valves display a ring of sub-marginal fultoportulae (Fig. 28, arrowed) that initiate distally an usually biseriate fascicle (Fig. 29). There are typically three oblique sub-marginal rimoportulae (Figs 28-29). Central area fultoportulae possess two (Fig. 29) or three (Fig. 30) satellite pores and occur in depressions near finely porate domed cribra (Fig. 30).

Size distributions:- To help substantiate the two varieties of $S$. neoeagypticus, diameters of 70 random valves (S. neoaegypticus sensu lato) were assigned to size classes and the distribution plotted (Fig. 31a). These data show a bimodal size distribution with two modal size classes, 30-40 $\mu \mathrm{m}$ and $50-60 \mu \mathrm{m}$; the larger class was always composed of $S$. neoaegypticus valves and the smaller class was mainly $S$. aegypticus var. fekrii. For $S$. galileensis, diameters of 60 random valves were assigned to size classes and the distribution plotted (Fig. 31b). There were approximately equal numbers of convex and concave valves resulting in a unimodal size class distribution with $35 \%$ of valves in the $30-35 \mu \mathrm{m}$ size class.
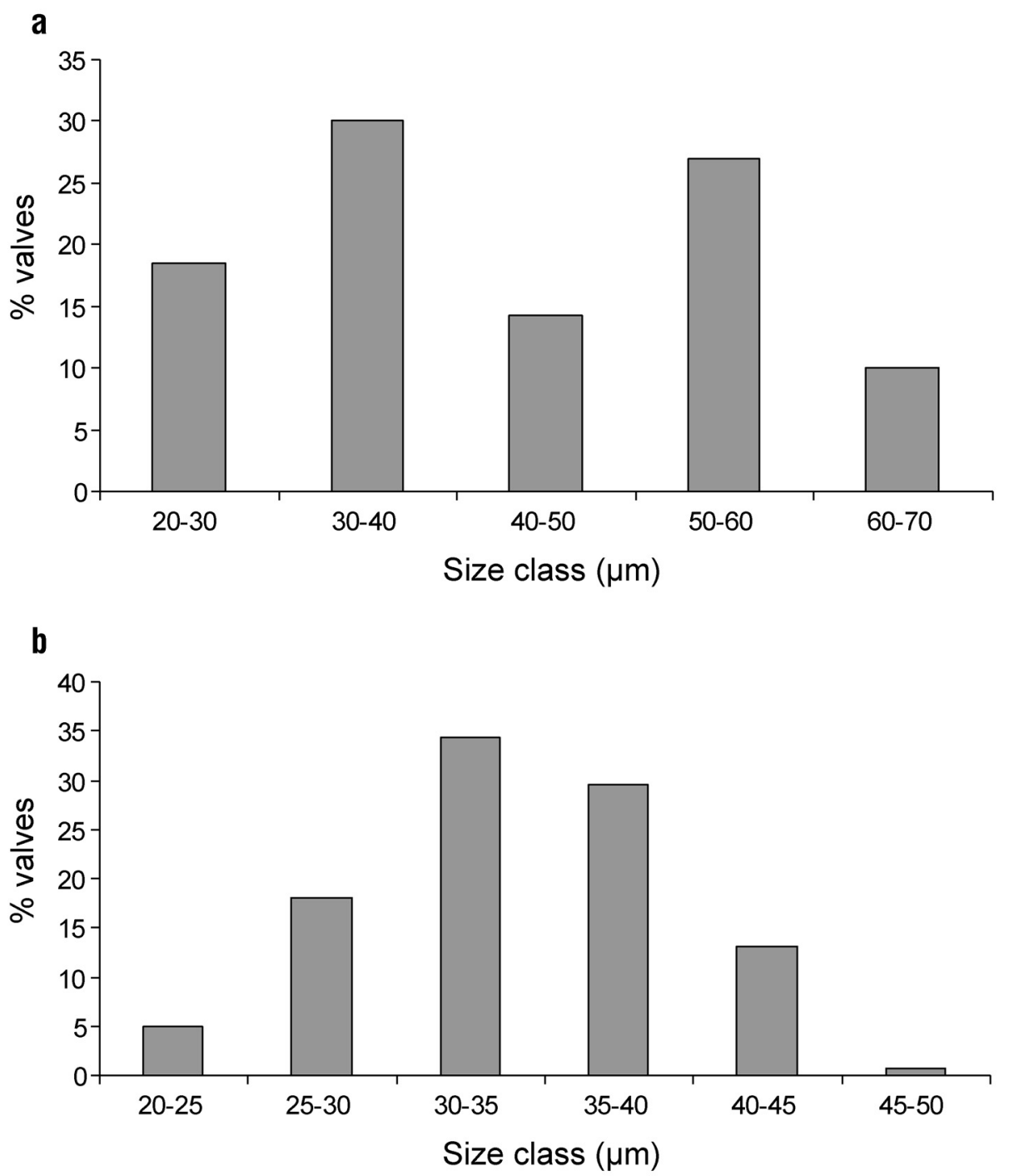

FIGURE 31. Size distributions for diatom valve diameters (see text). Fig. 31a: Stephanodiscus neoaegypticus sensu lato from material at $430 \mathrm{~cm}$ depth in core GARK1. Fig. 31b. Stephanodiscus galileensis Hakansson \& Ehrlich from material at $1930 \mathrm{~cm}$ depth in core QARU9.

Morphological comparisons:-The morphological characteristics of $S$. neoaegypticus and $S$. neoeagypticus var. fekrii are summarized in Table 1 where valve size, extent of uniseriate areolae serve best to discriminate the latter in routine LM examination. Another small form, similar to S. neoagypticus var. fekrii but with distally wider (4/5 areolae) fascicles, was recognised in GARK1 and tentatively named as cf. asteriodes but this taxon requires further study. Comparable data for $S$. aegyptiacus from Håkansson \& Locker 1981 are included in Table 1 to demonstrate differences between this species and the two newly 
described $S$. neoaegypticus taxa. The most discriminating features of the latter are a larger valve diameter range and differences in valve face areolar structure. Strongly concentric valve undulations a distinct marginal hyaline ring and marginal spines are all lacking in $S$. neoaegypticus sensu lato. The morphological characteristics of $S$. galileensis obtained from the Qarun core material compare favourably with the published data for this species (Håkansson \& Ehrlich 1987) shown in Table 2. The original description and the existence of heterovalvy is generally substantiated and only very minor differences were found in this study. The latter extends slightly the original description by increasing the valve size range and including more variation in the number of rimoportulae and in the arrangement of satellite pores around fultoportulae.

TABLE 1. Some morphological charcteristics of Stephanodiscus neoaegypticus Flower and S. neoaegypticus v. fekrii Flower. Data for S. aegyptiacus Ehr. from Håkansson \& Locker (1981) are also given for comparison; na indicates data not available, ? indicates inferred value.

\begin{tabular}{|c|c|c|c|}
\hline & S. neoaegypticus & S. aegypticus v. fekrii & S. aegyptiacus \\
\hline Diameter $(\mu \mathrm{m})$ & c. $30-70$ & c. $20-35$ & $9-45$ \\
\hline Concentric undulation & weak & weak & strong \\
\hline Spines & none & none & yes \\
\hline Interfascicles & hyaline, $4-5$ in $10 \mu \mathrm{m}$ & hyaline, 4 in $10 \mu \mathrm{m}$ & hyaline, $3-5$ in $10 \mu \mathrm{m}$ \\
\hline Fascicle areolae (proximal) & uniseriate & uniseriate & uniseriate \\
\hline Fascicle areolae (distal) & $2-4$ rows & $3-4$ rows & $2-4$ rows \\
\hline Uniserate areolae extent & $75-80 \%$ of valve & c. $50 \%$ of valve & c. $60 \%$ of valve \\
\hline Marginal hyaline ring & indistict or absent & absent & distinct \\
\hline Interfaciscle at mantle & rarely bifurcated & often bifurcated & na \\
\hline Areolae on mantle & fine, $3-4$ in $1 \mu \mathrm{m}$ & fine, $3-4$ in $1 \mu \mathrm{m}$ & fine, 3 in $1 \mu \mathrm{m}$ \\
\hline Interfascicles & width, $0.5-1.5 \mu \mathrm{m}$, not raised & width $0.5-1.5 \mu \mathrm{m}$, not raised & width $0.4-0.9 \mu \mathrm{m}$, raised \\
\hline External areolar pores & c. $0.2-1 \mu \mathrm{m}$, c. 14 in $10 \mu \mathrm{m}$ & c. $0.2 \mu \mathrm{m}$, c. 16 in $10 \mu \mathrm{m}$ & $>1 \mu \mathrm{m}, 6-7$ in $10 \mu \mathrm{m}$ \\
\hline Internal cribra & domed, c. $0.4 \mu \mathrm{m}$ & domed, c. $0.4 \mu \mathrm{m}$ & na \\
\hline Central area fultoportulae & up to 6 & 2 or 3 & $5 ?$ \\
\hline Marginal fultoportulae & interfascicle termini, raised & interfascicle termini, raised & interfascicle termini, below spines \\
\hline Satellite pores & 3 at margin, 2 centrally & $3 / 4$ at margin, 2 centrally & 3 at margin, 2 centrally \\
\hline Rimoportulae & 3-6, sub-marginal & usually 2 , sub-marginal & at least one, marginal \\
\hline
\end{tabular}

\section{Discussion}

The presence of diatom-rich marl sediment in the basal sections of all three cores provide evidence of a lake that was formerly much more extensive than today. The planktonic diatoms in these sections were dominated by Aulacoseira and Stephanodiscus taxa and, while A. granulata (Ehrenberg) Simonsen (1979: 58) is common in the Nile River today (Talling et al. 2009), the latter is not. Sediment records show that species of the genus Stephanodiscus were formerly widespread and often very abundant in large East African lakes during the Plio-Pleistocene and Holocene (Gasse 1980, 1987). However, few species present in the Faiyum core sections appeared to be recognisable as previously described African endemics. Those Stephanodiscus species present in the Faiyum sediments appear to have developed within the lake rather than from populations brought northwards into the lake via Nile floods.

In the thinly laminated marl sections of cores QARU9 and 10, Stephanodiscus galileensis was fairly common; it has not been previously reported for the Faiyum but its locality corresponds to the fossil type material from Lake Kinneret (Håkansson \& Erhlich 1987). The species seems to have a very restricted Middle Eastern distribution although Krammer \& Lange-Bertalot (2004) note that it is a planktonic form in eutrophic African freshwaters. Tuji et al. (2003) comment on the similarities of $S$. akanensis Tuji, Kawashima, Julius \& Stoermer (2003: 2) (so far a Japanese endemic species) to $S$. galileensis. Mueller-Wilmes (1988) recorded 11 unidentified Stephanodiscus species in Lake Qarun sediment cores and S. galileensis probably occurred 
within this unknown group. Other unidentified Stephanodiscus taxa could correspond to different dissolution states of this species where erosion of both the marginal and the broad interfascicle areas can alter markedly valve appearance in LM.

The marked heterovalvy in S. galileensis described by Håkansson \& Erhlich (1987) is supported in this investigation as are the characteristics of both the convex and concave valves. Failure to recognise this heterovalvic condition can also cause species identification problems in routine counting since the concave valve is distinctly more finely striated and has a higher density of fascicle areolae (cf. Table 2 ). As noted by Håkansson \& Erhlich (1987), the distinctive hyaline marginal ring is characteristic of the convex valve and, while not definitive of the species, it is a useful initial identification feature. The descriptions of both frustular valves of this species are extended slightly by reporting details ultra-structure features (cf. Table 2) associated with the valve processes and the valve size range is extended to smaller forms (to $20 \mu \mathrm{m}$ valve diameter).

The other Stephanodiscus species of note found to date in the Faiyum sediment cores is described as a new species Stephanodiscus neoaegypticus. This species occurred most commonly in GARK1, from a region that would have been partially isolated from the main lake in the early Holocene. Although the 'See Garak' area of the Faiyum is the type locality for Stephanodiscus aegyptiacus Ehr., this species appeared absent in Gharak sediment where only a few $S$. galileensis and the newly described species were common. Ehrenberg (1854) noted that $S$. aegyptiacus is an extinct form that also occurs in Atlantic Passat winds but the latter does not substantiate its occurrence as North African. Associated diatoms in his drawing (in Håkansson \& Locker 1981) do however indicate a sedimentary source within the Faiyum. The only extant lake (Birket Abu Talib) in the Gharak is small and shallow and receives agricultural drainage so is most unlikely to support $S$. aegyptiacus today. While its occurrence in the Faiyum remains to be established, the latter species seems unreported in recent lakes except for several sites in Florida (Whitmore 1989).

Despite the genus name, Stephanodiscus neoaegypticus is distinctive for its total lack of spines in all specimens examined in this study. While marginal spines are characteristic of the genus (e.g. Krammer \& Lange-Bertalot 1991) may other characters of S. neoaegypticus (fascicule structure, arrangement of valve face and mantle areolae, the external rimoportula and the criba) are all typical of Stephanodiscus. The new species has few characters in common with $S$. galileensis (cf. Tables $1 \& 2$ ). Similarly, it is clearly separated from $S$. aegyptiacus Ehr., a species for which heterovalvy is not confirmed (Håkansson \& Erhlich 1987). There are, however, issues with the description of $S$. aegyptiacus, the convex valve figured in SEM from the type material (Fig. 63 in Håkansson \& Locker 1981) has a marginal hyaline ring, raised interfascicular ribs and fascicular areolar structure exactly similar to $S$. galileensis. The internal valve image (Fig. 65 in Håkansson \& Locker 1981) of $S$. aegyptiacus shows a central area ring of fultoportulae and sub-marginal rimoportulae in the same positions as in $S$. galileensis. Further, an external valve of $S$. galileensis, Fig. 87 in Håkansson (2002), and the external valve of S. galileensis, Fig. 63 in Håkansson \& Locker (981) seem identical. The diagnosis of S. aegyptiacus is also virtually the same as that for the convex valve of S. galileensis excepting a smaller size limit for the former. As noted by Håkansson \& Locker (1981), other workers have expressed doubt in the validity of S. aegyptiacus (e.g. VanLandingham 1978) and while the species concept is valid, conspecificity with $S$. galileensis is suspected. If heterovalvy can be demonstrated in the original material of $S$. aegyptiacus, then $S$. galileensis may well be synonimous.

Validating and establishing diatom species in ancient lake sediments is often made difficult by poor preservation, but establishing a secure taxonomic foundation is essential to assure integrity for biostratigraphies within and between lakes. Furthermore, a secure taxonomy is needed for both extant and fossil species so that species distributions through time and space can be determined. Provenance of individual species as well as information about the diversity of either contemporary communities or fossil assemblages is needed to help understand how diatom diversity in ancient lakes developed and sometimes declined. Questions remain about the origin of the diatom species recorded in Lake Qarun sediments but it is already clear that the Stephanodiscus flora of the early Holocene deep lake arose and declined with some rapidity (cf. Flower et al. 2012). Until a secure chronology is developed for a continuous Holocene sequence for Lake Qarun, the precise timing of the major environmental changes in this once great lake remains elusive. 


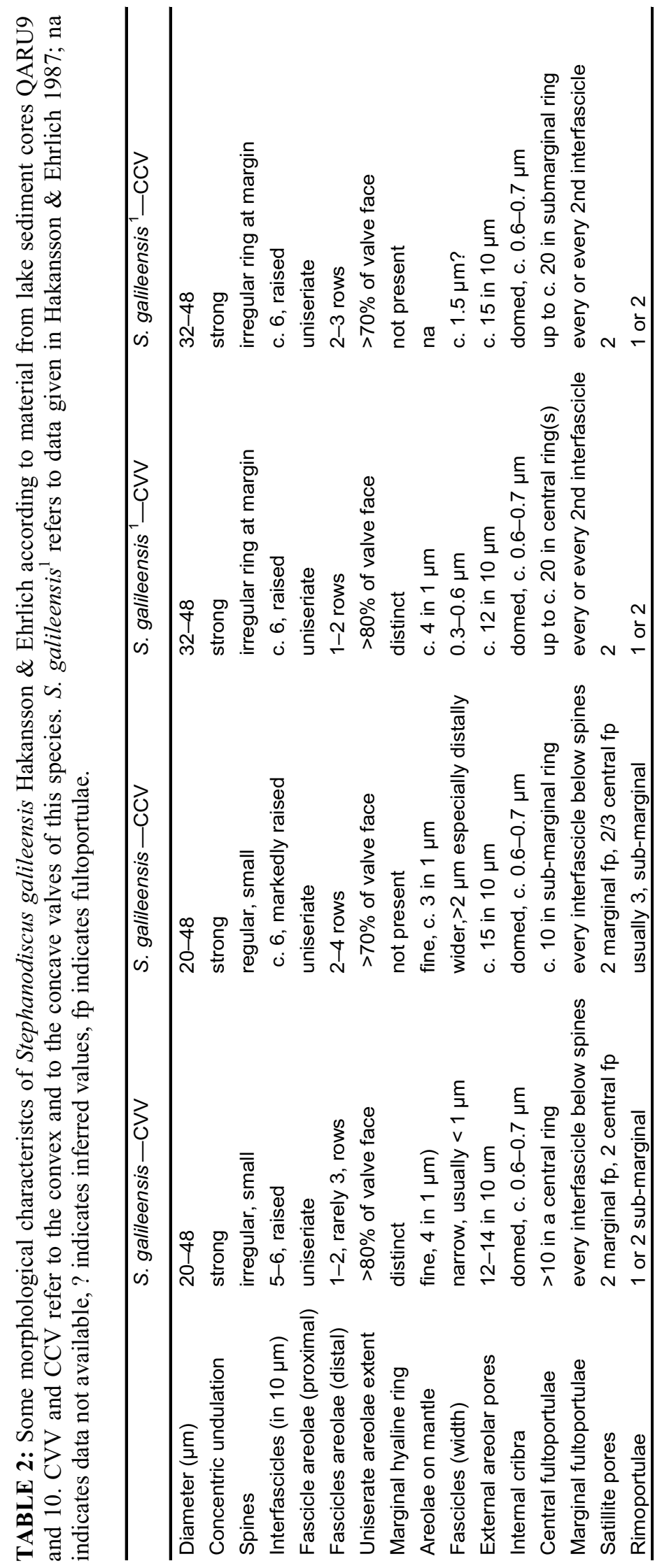




\section{Acknowledgments}

We wish to thank the British Academy for supporting this work through their grant (LG426). We are also grateful to the Egyptian team for collecting the sediment cores. Artwork is by Miles Irving (UCL). David Ryves (Loughborough University) kindly facilitated the light microphotography and James Davy (UCL) helped with the SEM work.

\section{References}

Aleem, A.A. (1958) A taxonomic and palaeoecological investigation of the diatom flora of the extinct Fayoum Lake (Upper Egypt). University of Alexandria Bulletin 2: 217-44.

Caton-Thompson, G. \& Gardner, E.W. (1934) The Desert Faiyum. Royal Anthropological Institute, London, 167 pp.

Ehrenberg, C.G. (1830) Organisation, Systematik und geographisches Verhältniss der Infusionsthierchen. Zwei verträge. Abhandlungen der Königlichen Akademie der Wissenschaften zu Berlin 108 pp.

Ehrenberg, C.G. (1845) Neue Untersuchungen über das kleinste Leben als geologisches Moment. Bericht über die zur Bekanntmachung geeigneten Verhandlungen der Königlich-Preussischen Akademie der Wissenschaften zu Berlin 1845: 53-87.

Ehrenberg, C.G. (1854) Mikrogeologie. Das Erden and Felsen schaffende Wirken des unsichbar kleinen selbststandigen Lebens auf der Erde. Leipzig, 374 pp.

Fathi, A.A. \& Flower, R.J. (2005) Water quality and phytoplankton communities in Lake Qarun (Egypt). Aquatic Sciences 67: 350-362.

Flower, R.J., Stickley, C., Rose, N.L., Peglar, S., Fathi, A.A. \& Appleby, P.G. (2006) Environmental change at the desert margin: an assessment of recent paleolimnological records in Lake Qarun, Middle Egypt. Journal of Paleolimnology 35: $1-24$. http://dx.doi.org/10.1007/s10933-005-6393-2

Flower, R.J., Keatings, K., Hamdan, M., Hassan, F.A., Boyle, J.F., Yamada, K. \& Yasuda, Y. (2012) The structure and significance of early Holocene laminated lake sediments in the Faiyum Depression (Egypt) with special reference to diatoms. Diatom Research 27: 127-140. http://dx.doi.org/10.1080/0269249X.2012.703624

Gasse, F. (1980) Les diatomées lacustres pliopléistocènes du Gadeb (Ethiopie). Systématique, paléoécologie, biostratigraphie. Revue Algologique Mémoire Hors-Série. 3: 1-249.

Gasse, F., Fontes, J.C., Plaziat, J.C., Carbonel, P., Kaczmarska, I., De Deckker, P., Soulie-Marsche, I., Callot, Y. \& Dupeuble, P.A. (1987) Biological remains, geochemistry and stable isotopes for the reconstruction of environmental and hydrological changes in the Holocene lakes from North Sahara. Palaeography, Palaeoclimatology, Palaeoecology 60: 1-46. http://dx.doi.org/10.1016/0031-0182(87)90022-8

Håkansson, H. \& Ehrlich, A. (1987) Stephanodiscus galileensis sp. nov. from Holocene subsurface sediments of Lake Kinneret, Israel. Diatom Research 2: 15-21. http://dx.doi.org/10.1080/0269249X.1987.9704981

Håkansson, H. \& Locker, S. (1981) Stephanodiscus Ehrenberg 1846, a revision of the species described by Ehrenberg. Nova Hedwigia 35: 117-150.

Håkansson, H. (2002) A compilation and evaluation of species in the genera Stephanodiscus, Cyclostephanos and Cyclotella with a new genus in the Stephanodiscaceae. Diatom Research 17: 1-139.

http://dx.doi.org/10.1080/0269249X.2002.9705534

Hassan, F.A. (1986) Holocene lakes and prehistoric settlements of the Western Faiyum, Egypt. J. Archaeological Science 13: 486-501. http://dx.doi.org/10.1016/0305-4403(86)90018-X

Keatings, K., Holmes, J.A., Flower, R.J. Horne, D., Whittiker, J.E. \& Abu-Zied, R.H. (2010) Ostracods and the Holocene palaeolimnology of Lake Qarun, with special reference to past human-environment interactions in the Faiyum (Egypt). Hydrobiologia 654: 155-176. http://dx.doi.org/10.1007/s10750-010-0379-4

Krammer, K. \& Lange-Bertalot, H. (1991) Bacillariophyceae, 3. Teil: Centrales, Fragilariaceae, Eunotiaceae. Band 2. In: Ettl, H., Gerloff, J., Heynig, H. \& Mollenhauer, D. (eds), Süßwasserflora von Mitteleuropa. Gustav Fischer Verlag, Stuttgart, $576 \mathrm{pp}$.

Kützing, F.T. (1844) Die Kieselschaligen. Bacillarien oder Diatomeen. Nordhausen. 152 pp., 30 pls. 
Mansour, A.H. (2008) Natural and propagated algal flopa isolated from El-Fayum Governorate. Egyptian Journal of Biology 10: 54-61.

Mueller-Wilmes, B. (1988) Diatomeen aus Holozaenen sedimenten des Fayum-Sees, Aegypten. Geologisches Institut der Universitat zu Koeln Sonderveroeffentlichungen, No. 4, F. Hansen, Koeln. 114 pp.

Przybylowska-Lange, W. (1976) Diatoms from the Site E71K14, Area 1, Trench 1, upper diatomaceous silt. In: F. Wendorf \& R. Schild (Eds), Prehistory of the Nile Valley. Academic Press, New York, pp 321-323.

Simonsen, R. (1979) The diatom system: ideas on phylogeny. Bacillaria 2: 9-71.

Talling, J.F., Sinada, F., Taha, O. E. \& Sobhy, E.M.H. (2009) Phytoplankton: composition, development and productivity. In: H. J. Dumont (Ed.), The Nile, Origin, Environments, Limnology and Human Use. Monographiae Biologicae 89. Springer, Dordrecht, pp. 431-462.

Theriot, E. \& Håkansson, H., Kociolek, J.P., Round, F.E. \& Stoermer, E.F. (1987) Validation of the centric diatom genus name Cyclostephanos. British Phycological Journal 22: 345-347. http://dx.doi.org/10.1080/00071618700650411

Thwaites, G.H.K. (1848) Further observations on the Diatomaceae with descriptions of new genera and species. Annals and Magazine of Natural History, 2nd series, 1: 161-172.

Tuji, A., Kawashima, A., Julius, M.L. \& Stoermer E.F. (2003) Stephanodiscus akanensis sp. nov. a new species of extant diatom from Lake Akan. Bulletin of the Natural Sciences Museum of Tokyo, Series B 29: 1-8.

Whitmore, T.J. (1989). Florida diatom assemblages as indicators of trophic state and pH. Limnology \& Oceanography 34: 882-895.

http://dx.doi.org/10.4319/lo.1989.34.5.0882

VanLandingham, S.L. (1967-78) Catalogue of the Fossil and Recent Genera and Species of Diatoms and their Synonyms. Lehre. 